\title{
Diet effects on glucose absorption in the small intestine of neonatal calves: Importance of intestinal mucosal growth, lactase activity, and glucose transporters
}

\author{
Julia Steinhoff-Wagner, ${ }^{*}$ Rudolf Zitnan, † Ulrike Schönhusen, ${ }^{*}$ Helga Pfannkuche,‡ Monika Hudakova,§ \\ Cornelia C. Metges, ${ }^{*}$ and Harald M. Hammon*1 \\ *Institute of Nutritional Physiology "Oskar Kellner," Leibniz Institute for Farm Animal Biology (FBN), 18196 Dummerstorf, Germany \\ †Institute of Nutrition, National Centre of Agriculture and Food Nitra, 04181 Kosice, Slovakia \\ ¥Institute of Veterinary-Physiology, Leipzig University, 04103 Leipzig, Germany \\ $\S$ School of Economics and Management in Public Administration, 85104 Bratislava, Slovakia
}

\section{ABSTRACT}

Colostrum (C) feeding in neonatal calves improves glucose status and stimulates intestinal absorptive capacity, leading to greater glucose absorption when compared with milk-based formula feeding. In this study, diet effects on gut growth, lactase activity, and glucose transporters were investigated in several gut segments of the small intestine. Fourteen male German Holstein calves received either $\mathrm{C}$ of milkings 1,3 , and 5 (d 1,2, and 3 in milk) or respective formulas (F) twice daily from d 1 to d 3 after birth. Nutrient content, and especially lactose content, of $\mathrm{C}$ and respective $\mathrm{F}$ were the same. On d 4, calves were fed $\mathrm{C}$ of milking 5 or respective $\mathrm{F}$ and calves were slaughtered $2 \mathrm{~h}$ after feeding. Tissue samples from duodenum and proximal, mid-, and distal jejunum were taken to measure villus size and crypt depth, mucosa and brush border membrane vesicles (BBMV) were taken to determine protein content, and mRNA expression and activity of lactase and mRNA expression of sodium-dependent glucose cotransporter-1 (SGLT1) and facilitative glucose transporter (GLUT2) were determined from mucosal tissue. Additionally, protein expression of SGLT1 in BBMV and GLUT2 in crude mucosal membranes and BBMV were determined, as well as immunochemically localized GLUT2 in the intestinal mucosa. Villus circumference, area, and height were greater, whereas crypt depth was smaller in $\mathrm{C}$ than in F. Lactase activity tended to be greater in C than in F. Protein expression of SGLT1 was greater in $\mathrm{F}$ than in $\mathrm{C}$. Parameters of villus size, lactase activity, SGLT1 protein expression, as well as apical

Received May 20, 2014.

Accepted June 28, 2014.

${ }^{1}$ Corresponding author: hammon@fbn-dummerstorf.de and basolateral GLUT2 localization in the enterocytes differed among gut segments. In conclusion, C feeding, when compared with $\mathrm{F}$ feeding, enhances glucose absorption in neonatal calves primarily by stimulating mucosal growth and increasing absorptive capacity in the small intestine, but not by stimulating abundance of intestinal glucose transporters.

Key words: colostrum, intestinal mucosa growth, lactase, glucose transporter

\section{INTRODUCTION}

At birth, the gastrointestinal tract (GIT) of neonatal mammals copes with the shift from parental nutrition via the placenta to enteral nutrition after birth. Colostrum intake provides high amounts of fats, proteins, and peptides, fat-soluble vitamins, and various enzymes, hormones, growth factors, cytokines, minerals, and nucleotides. Their concentrations peak immediately after delivery (except for lactose) and decrease markedly during the first $3 \mathrm{~d}$ of lactation to those typical for mature milk (Blum and Hammon, 2000; Gauthier et al., 2006; Hammon et al., 2013). Colostrum intake in neonatal calves is essential for passive immunity and energy supply (Blum, 2006). However, glucose intake from colostrum does not meet glucose demands during neonatal life (Girard, 1990; Hammon et al., 2013).

Absorption of colostral immunoglobulins, some other proteins, and enzymes occurs during the first hours after birth (Michanek et al., 1990; Baumrucker and Blum, 1994), whereas ingested growth factors (e.g., IGF-I) and hormones (e.g., insulin and prolactin) marginally pass into circulation in newborn calves (Grütter and Blum, 1991; Baumrucker et al., 1994; Lee et al., 1995; Vacher et al., 1995; Hammon and Blum, 1997b) and pigs (Burrin et al., 1996; Odle et al., 1996) and exert their effects primarily locally in the GIT. Colostrum intake stimulates development and function of the 
GIT in neonatal calves (Bühler et al., 1998; Blum and Hammon, 2000; Blättler et al., 2001) and pigs (Simmen et al., 1990; Odle et al., 1996; Xu et al., 2002). Stimulatory components of colostrum target intestinal epithelial growth (Baumrucker et al., 1994; Blättler et al., 2001; Roffler et al., 2003) and cause more effective absorption of glucose (Steinhoff-Wagner et al., 2011; Hammon et al., 2012). This assumption is supported by the observation in neonatal calves that intestinal absorptive capacity for xylose, a pentose sugar that is absorbed by the same transporters as glucose (Scharrer and Grenacher, 2000), responded to colostrum and less to milk replacer or formula feeding, which contained only trace amounts of IGF-I and insulin (Hammon and Blum, 1997a; Kühne et al., 2000; Rauprich et al., 2000; Sauter et al., 2004).

In neonatal mammals, lactose is the main nutritive carbohydrate source and lactose is split into glucose and galactose by intestinal lactase activity. Intake of colostrum may stimulate small intestinal lactase activity in calves, as shown in other species (Bird et al., 1996; Tivey et al., 1994). The intestinal absorption of glucose occurs predominantly in the duodenum, jejunum, and in the ileum to a lesser degree (Shirazi-Beechey et al., 1995) by active transport at the apical side whereby sodium-dependent glucose co-transporter 1 (SGLT1) transports monosaccharides from the intestinal lumen across the brush border membrane in a competitive process (Shirazi-Beechey et al., 1995). Glucose and galactose transport continues across the basolateral membrane by facilitated glucose transport (GLUT2; Shirazi-Beechey et al., 1995). Glucose transport can be influenced by feeding and it has been confirmed that the intrinsic activity of GLUT2 increases with elevated luminal glucose concentration and by trafficking GLUT2 to the apical membrane (Kellett and Helliwell, 2000; Kellett et al., 2008).

Based on these premises, we tested the hypothesis that feeding colostrum to neonatal calves after birth stimulates villus growth, lactase activity, and glucose transporters in the small intestine compared with milkbased formula feeding, resulting in a greater glucose absorption in colostrum- than formula-fed calves, as recently shown (Steinhoff-Wagner et al., 2011; Hammon et al., 2012). Tissue samples of several gut segments were harvested $2 \mathrm{~h}$ after milk intake on d 4 of life to investigate effects of feeding colostrum or a milk-based formula on mucosal growth and glucose transporters in different gut segments of the small intestine. Colostrum- and formula-fed calves consumed the same amounts of lactose and other macronutrients, but differed in a markedly smaller or even lacking intake of bioactive substances.

\section{MATERIALS AND METHODS}

\section{Animals, Husbandry, and Feeding}

The experimental procedures were carried out according to the German animal care guidelines and were approved by the relevant authorities of the State Mecklenburg-Vorpommern, Germany (LALLF M-V/ TSD/7221.3-1.1-014/07).

Fourteen male German Holstein calves were investigated from birth to d 4 of life. Calves were born at neighboring farms and were transported immediately after birth to the experimental barn. All calves were singletons and spontaneously born to multiparous cows after normal lengths of gestation. Calves were kept in single boxes at the Research Station of the University of Rostock (Dummerstorf, Germany), housed at a mean room temperature of $19^{\circ} \mathrm{C}$ with straw bedding and free access to water. They were randomly assigned to 2 treatment groups [colostrum $(\mathbf{C})$ and formula $(\mathbf{F}) ; \mathrm{n}$ $=7$ each . Calves of group $\mathrm{C}$ received pooled colostrum obtained from milkings 1 (d 1), 3 (d 2), and 5 (d 3) for the first $3 \mathrm{~d}$. Calves of group $\mathrm{F}$ were fed 3 differently composed milk-based formulas on $\mathrm{d} 1,2$, and 3 that contained amounts of macronutrients comparable to those of the respective colostrum milkings. On d 4 calves were fed either colostrum of milking 5 or formula 3 for groups $\mathrm{C}$ and $\mathrm{F}$, respectively. Colostrum and formula amounts fed were targeted to be $8 \%$ of BW on d 1 and $10 \%$ of BW from d 2 in 2 daily portions $(0800$ and $1600 \mathrm{~h}$ ) and only 1 portion on d 4 in amounts of $5 \%$ of BW. Calves received their first meal at $4.4 \pm 0.6$ $\mathrm{h}$ after birth.

Colostrum was collected from the farms where calves originated 2 mo before the beginning of the study. Cows were milked twice daily and the colostrum of the milkings 1, 3, and 5 after parturition was stored separately in plastic bottles at $-20^{\circ} \mathrm{C}$. Three formula premixes were created to contain nutrients (protein, fat, lactose) in comparable amounts as in colostrum of milkings 1, 3, and 5 after parturition. Formula premixes were provided by Bergophor Futtermittelfabrik GmbH (Kulmbach, Germany). The 3 formula premixes were dissolved by adding water and stored in plastic bottles at $-20^{\circ} \mathrm{C}$ until use. Composition of colostrum milkings and respective formulas is given in Supplemental Table 1 of Steinhoff-Wagner et al. (2011).

\section{Intestinal Tissue Sampling}

Calves were slaughtered $2 \mathrm{~h}$ after feeding on $\mathrm{d} 4$. The small intestine was removed and the lumen was cleaned with an ice-cold physiological saline solution. Tissue 
samples were taken from mid-duodenum and proximal, mid-, and distal jejunum, frozen in liquid nitrogen, and stored at $-80^{\circ} \mathrm{C}$ until analyzed. Additionally samples of respective gut segments were opened longitudinally and mucosa samples were scraped off with a microscope slide, snap-frozen in liquid nitrogen, and stored at $-80^{\circ} \mathrm{C}$ until analyzed or cut in $1-\mathrm{cm}^{2}$ pieces and fixed in $4 \%$ formaldehyde solution for morphometrical measurements or in Histofix (Roth, Karlsruhe, Germany) for immunohistochemistry.

\section{Morphometrical Measurements}

Formaldehyde-fixed tissue samples were rinsed in water, dehydrated in a graded series of ethanol $(30,50$, 70 and 90\%), cleared in benzene, and saturated with and embedded in paraffin. Sections of $5 \mu \mathrm{m}$ in thickness (10 slices of each sample) were stained with hematoxylin and eosin and observed under a light microscope. The height, circumference, and cut surface area of 30 villi and depth of 30 crypts were determined by the computer-operated Image $\mathrm{C}$ picture analysis system (Imtronic GmbH, Berlin, Germany) and the IMES analysis program by using a color video camera (SONY 3 CCD, Sony Electronics Ltd., Tokyo, Japan) and a light microscope (Axiolab, Carl Zeiss Jena, Germany; Zitnan et al., 2008).

\section{Lactase Activity Assay}

The activity of lactase (EC 3.2.1.23.) was measured according to Mir et al. (1997). Briefly, frozen mucosal tissue (200-mg sample homogenized in $1 \mathrm{~mL}$ of saline for $3 \mathrm{~min}$ ) was washed in a test tube using two 2.5$\mathrm{mL}$ aliquots of saline solution $(0.9 \% \mathrm{NaCl}$, wt/vol). Of the homogenate, $100 \mu \mathrm{L}$ were transferred to a reaction tube and placed in a water bath $\left(37^{\circ} \mathrm{C}\right)$, then $400 \mu \mathrm{L}$ of $56 \mathrm{~m} M$ lactose in citrate buffer ( $\mathrm{pH}$ 6.6, $0.01 M)$ were added, respectively. After shaking and incubation for $30 \mathrm{~min}$, the enzyme activity was stopped in boiling water. The tubes were centrifuged $(2,000 \times g, 15$ min at $\left.4^{\circ} \mathrm{C}\right)$. Galactose produced during the incubation with tissue homogenate was measured to determine the activity of lactase. Concentrations of galactose in the supernatant were determined by a UV method (UV Test Lactose/D-Galactose No. 1763030, Boehringer Mannheim/R-Biopharm, Mannheim, Germany).

\section{Quantification of SGLT1, GLUT2, and Lactase mRNA by Real-Time PCR}

Frozen mucosa samples were ground in liquid nitrogen immediately before analysis. Total DNA and RNA were extracted using TRIzol Reagent (Invitrogen, Karlsruhe, Germany), resuspended in RNase-free water, and quantified by UV absorption. The integrity and purity of RNA were tested by measurement of optical density (ratios at 260 and $280 \mathrm{~nm}$ being greater than 1.9) and by electrophoresis using ethidium bromide staining. A total of $1 \mu \mathrm{g}$ of RNA was reverse transcribed into cDNA using random primers (Invitrogen) and purified using the High Pure PCR Product Purification Kit (Roche Diagnostics, Mannheim, Germany; Hammon et al., 2009).

Real time reverse transcription PCR was performed by LightCycler (Roche Molecular Biochemicals, Mannheim, Germany) using SYBR Green I as fluorescence dye (Hammon et al., 2009). Specific primers were used to measure the mRNA concentrations of SGLT1, GLUT2, lactase, ribosomal protein S9, and $\beta$-actin. Sequences of all primers have been published (Ontsouka et al., 2004; Hammon et al., 2009; Lohrenz et al., 2011). Primers were designed to flank a region that contains at least 1 intron to ensure that no contaminating genomic DNA was amplified that could lead to false signals.

Melting temperatures that were performed by the LightCycler in a melting curve analysis program after the last amplification cycle demonstrated specific PCR products. Upon agarose gel electrophoresis, all PCR products moved in 1 single band and showed the expected size (Ontsouka et al., 2004; Hammon et al., 2009; Lohrenz et al., 2011). Products for SGLT1 and $\beta$-actin were verified by sequencing using an $\mathrm{ABI}$ Sequencing kit (ABI Big Dye Terminator, Applied Biosystems, Darmstadt, Germany) and an ABI 310 Genetic Analyzer (Applied Biosystems).

Quantification of mRNA was performed by relative expression using mean of $\beta$-actin and ribosomal protein S9 as a reference gene transcript (Pfaffl, 2001; Hammon et al., 2009). Efficiencies of PCR were $>1.8$. Expression of the reference gene in our study was not affected by diet or gut segment. Inter- and intraassay CV for real time PCR of target and reference genes were below $1 \%$, respectively.

\section{Measurements of SGLT1 and GLUT2 Protein}

Preparation of brush-border membrane vesicles (BBMV) were performed as described (Schröder and Breves, 1996; Lohrenz et al., 2011) with few modifications (Lohrenz et al., 2011). The final protein concentration in BBMV was 10 to $20 \mathrm{mg} / \mathrm{mL}$. Portions (200 $\mu \mathrm{L}$ ) of BBMV were frozen in liquid nitrogen and stored until analyzed. Purity of BBMV was determined by marker enzymes: alkaline phosphatase activity (ALP; EC 3.1.3.1; Kit No. 816388 Roche Diagnostics) and 
ouabain-sensitive $\mathrm{Na}^{+}-\mathrm{K}^{+}$-activated ATPase $\left(\mathrm{Na}^{+}-\mathrm{K}^{+}\right.$ATPase, EC 3.6.1.3; Fujita et al., 1971) were determined. Because, on a protein basis, ALP was 23 -fold and $\mathrm{Na}^{+}-\mathrm{K}^{+}$-ATPase was 1.4 -fold more enriched in BBMV suspensions than in the corresponding homogenates, concentrations of brush border membranes in final BBMV preparations were satisfactory (Schröder and Breves, 1996). Protein concentrations of BBMV were determined according to the Bradford (1976) method with BSA (Sigma-Aldrich Co., St. Louis, MO) as a standard. For the preparation of crude cell membranes mucosa tissue was homogenized and centrifuged as described (Lohrenz et al., 2011).

Protein expression of SGLT1 in BBMV, as well as GLUT2 in BBMV and cell crude membranes, were quantified by SDS PAGE (7.5\% acrylamide) and immunoblot analyses (Lohrenz et al., 2011). Gel electrophoresis was performed using a Mini-Protean Electrophoresis System (Bio-Rad Laboratories GmbH, München, Germany) and protein markers (Precision Plus Protein, Bio-Rad Laboratories $\mathrm{GmbH}$ ) as a molecular mass standard. Proteins were transferred from the gel onto nitrocellulose membrane (GE Healthcare, Buckinghamshire, UK) and blocked with TBS-T (20 $\mathrm{m} M$ Tris- $\mathrm{HCl}, \mathrm{pH} 7.6,137 \mathrm{mM} \mathrm{NaCl}$, and $50 \mathrm{~mL} / \mathrm{L}$ of Tween 20) containing $0.5 \%$ nonfat dry milk powder (Carl Roth GmbH, Karlsruhe, Germany). Membranes were incubated overnight at $4^{\circ} \mathrm{C}$ with rabbit anti-SGLT1 (1:1,000; Biotrend, Köln, Germany) or with rabbit antiGLUT2 (1:750, Biotrend), respectively. After washing membranes with TBS-T $(1 \times 15 \mathrm{~min} ; 2 \times 15 \mathrm{~min})$, they were incubated for $1 \mathrm{~h}$ at room temperature with horseradish peroxidase-conjugated sheep anti-rabbit IgG (1:10,000; Serotec, Kidlington, Oxford, UK) followed by visualizing with chemiluminescence (ECL Western Blotting Analysis System, GE Healthcare). The blot was autoradiographed (Hyperfilm ECL, Amersham Bioscience, Buckinghamshire, UK) and quantified by densitometry (Molecular Imaging Systems version 4.0, Eastman Kodak Company, Rochester, NY). Data were normalized to control preparations and reported as relative arbitrary units.

\section{Immunohistochemistry}

Specimens fixed in Histofix were washed $(3 \times 10$ min) with $0.1 M$ PBS for $24 \mathrm{~h}$ after sampling. Immunohistochemical labeling was performed on Cryostat sections after incubation overnight at $4^{\circ} \mathrm{C}$ in PBS containing $30 \%$ sucrose. Transversal sections $(15 \mu \mathrm{m})$ were cut using a cryostat, mounted on poly-L-lysine-coated slides and stored at $-20^{\circ} \mathrm{C}$. Sections were processed for fluorescence immunohistochemistry by washes (3 $\times 10 \mathrm{~min})$ in $\mathrm{PBS}$ and preincubation for $60 \mathrm{~min}$ in buffer solution (PBS containing 4\% horse serum and $0.5 \%$ Triton X-100; Pfannkuche et al., 2014). This buffer solution was also used for dilution of primary and secondary antibodies. After preincubation, the tissues were incubated with rabbit-anti-GLUT2 (sc-9117, Santa Cruz, Heidelberg, Germany) primary antibodies in a dilution of 1:50 for $18 \mathrm{~h}$ at room temperature. The tissues were then washed in PBS $(3 \times 10 \mathrm{~min})$ before they were incubated in buffer solution containing the secondary antibodies. Secondary anti-rabbit IgG raised in donkeys and conjugated to Cy2 (Dianova, Hamburg, Germany) were used in a dilution of 1:200. In some additional staining, specificity of the immune reactions was proven by omitting the primary antibodies. After the final washings, the specimens were cover-slipped with a solution of $\mathrm{NaHCO}_{3} / \mathrm{Na}_{2} \mathrm{CO}_{3}(0.5 \mathrm{M}, \mathrm{pH}$ 7.0) containing $0.1 \% \mathrm{NaN}_{3}$ and $80 \%$ glycerol. The stained sections were analyzed using an epifluorescence microscope (IX50, Olympus Corp., Tokyo, Japan) with a black and white video camera (F-view, Olympus, Hamburg, Germany) attached to an image analysis system (cell F, Olympus). From each animal and intestinal compartment stained, 2 sections were analyzed. Three photomicrographs were taken from each section. The magnification used was 200-fold and the exposure time was $200 \mathrm{~ms}$. Immunoreactivity was evaluated separately for apical and basolateral membranes of the epithelial cells in an arbitrary scale from 0 (no immunoreaction) to 3 (highest immunoreaction) in intervals of 0.5 .

\section{Statistical Analysis}

The statistical analysis was done with the program SAS (version 9.3; SAS Institute Inc., Cary, NC) using the procedure Mixed Model with feeding (C vs. F) and gut segment as fixed effects and the individual calf as random effect. Intestinal segment was treated as repeated measures. For all tests, differences with $P<$ 0.1 were defined as trend and with $P<0.05$ were assessed to be significant. Ranks representing histological immunoreactivity were compared separately for each gut segment in regard to different feeding, between gut segments regardless of feeding, and between localization (apical vs. basolateral) regardless of feeding within each gut segment with Wilcoxon Two-Sample Test.

\section{RESULTS}

\section{Mucosal Growth}

Morphometric results are shown in Table 1. Villus size (circumference, area, and height, respectively), crypt depth, and the villus height-to-crypt depth ratio were affected by diet and gut segment, respectively $(P$ 
$<0.05)$. Duodenal villus circumference in both groups was lower $(P<0.05)$ than in all gut segments of the jejunum; however, in $\mathrm{F}$, villus circumference in proximal jejunum was only in tendency higher $(P<0.1)$ than in duodenum. Colostrum-fed calves had a greater $(P<$ $0.05)$ villus circumference than $\mathrm{F}$. Villus area was lower $(P<0.05)$ in duodenum than in proximal (for $\mathrm{C}$ only) and mid-jejunum, whereas villus area in distal jejunum of both groups was in tendency lower $(P<0.1)$ than in mid-jejunum. Colostrum-fed calves had a greater overall villus area $(P<0.01)$ than $\mathrm{F}$. Villus height of $\mathrm{C}$ in the mid-jejunum was higher $(P<0.05)$ compared with distal jejunum in $\mathrm{C}$ and mid-jejunum in $\mathrm{F}$. Crypt depth was lowest $(P<0.05)$ in the mid-jejunum of both groups and higher $(P<0.05)$ in the duodenum of $\mathrm{F}$ than $\mathrm{C}$. Villus height-to-crypt depth ratio in $\mathrm{C}$ was highest in the mid-jejunum and was higher $(P<0.05)$ than in mid-jejunum of $\mathrm{F}$.

Mucosal protein concentrations (Table 2) in F were higher in the duodenum than in the distal jejunum and tended to be higher $(P<0.1)$ than in duodenum of $\mathrm{C}$. Vesicle protein concentrations were higher $(P<0.05)$ in proximal and mid-jejunum than in distal jejunum in both groups and duodenum in $\mathrm{C}$, and lower $(P<0.05)$ in mid-jejunum of $\mathrm{F}$ than of $\mathrm{C}$. Concentrations of RNA and DNA did not differ between different diets or gut segments.

\section{Lactase Activity and RNA Abundance}

Lactase activity (Table 2) related to mucosal tissue weight was lower in distal jejunum of $\mathrm{C}$ compared with other jejunal segments and was also lowest in distal jejunum of F. In both groups, lactase activity related to mucosal protein was lower in distal than in proximal and mid-jejunum and lactase activity per mucosal protein was in tendency higher $(P<0.1)$ in $\mathrm{C}$ than in F. Lactase mRNA expression showed in tendency $(P$ $<0.1$ ) an effect of gut segment, but no diet effect was observed.

\section{Glucose Transporters in the Small Intestine}

The ALP ratio did not show any effects of diet and gut segment (data not shown). Results concerning mRNA abundance of SGLT1 and GLUT2 in the mucosa of

Table 1. Villus circumferences, areas, and heights and crypt depths in duodenum and proximal, mid-, and distal jejunum in neonatal calves fed either colostrum or formula after birth for $4 \mathrm{~d}^{1}$

\begin{tabular}{|c|c|c|c|c|c|c|}
\hline \multirow[b]{2}{*}{ Trait } & \multicolumn{2}{|c|}{ Diet } & \multirow[b]{2}{*}{ SEM } & \multicolumn{3}{|c|}{ ANOVA $P$-value } \\
\hline & Colostrum & Formula & & Diet & $\begin{array}{c}\text { Gut } \\
\text { segment }\end{array}$ & $\begin{array}{c}\text { Diet } \\
\times \text { segment }\end{array}$ \\
\hline \multicolumn{7}{|c|}{ Villus circumference, $\mu \mathrm{m}$} \\
\hline Duodenum & $1,384^{\mathrm{b}}$ & $1,341^{\mathrm{b}}$ & 23 & 0.05 & 0.001 & 0.6 \\
\hline Proximal jejunum & $1,553^{\mathrm{a}}$ & $1,464^{\mathrm{ab}}$ & 23 & & & \\
\hline Mid-jejunum & $1,594^{\mathrm{a}}$ & $1,493^{\mathrm{a}}$ & 23 & & & \\
\hline \multirow{2}{*}{\multicolumn{7}{|c|}{$\begin{array}{l}\text { Vistar jejunum } \\
\text { Villus area, } \mu \mathrm{m}^{2}\end{array}$}} \\
\hline & & & & & & \\
\hline Duodenum & $66,647^{\mathrm{b}}$ & $63,434^{\mathrm{b}}$ & 1,252 & 0.01 & 0.001 & 0.7 \\
\hline Proximal jejunum & $76,552^{\mathrm{a}}$ & $70,893^{\mathrm{ab}}$ & 1,252 & & & \\
\hline Mid-jejunum & $79,710^{\mathrm{a}}$ & $72,873^{\mathrm{a}}$ & 1,252 & & & \\
\hline Distal jejunum & $74,023^{\mathrm{ab}}$ & $70,476^{\mathrm{ab}}$ & 1,252 & & & \\
\hline \multicolumn{7}{|l|}{ Villus height, $\mu \mathrm{m}$} \\
\hline Duodenum & $575^{\mathrm{ab}}$ & 556 & 14 & 0.01 & 0.01 & 0.08 \\
\hline Proximal jejunum & $593^{\mathrm{ab}}$ & 512 & 14 & & & \\
\hline Mid-jejunum & $654^{\mathrm{a}}$ & $554^{*}$ & 14 & & & \\
\hline Distal jejunum & $561^{\mathrm{b}}$ & 528 & 14 & & & \\
\hline \multicolumn{7}{|l|}{ Crypt depth, $\mu \mathrm{m}$} \\
\hline Duodenum & $226^{\mathrm{a}, \mathrm{b}}$ & $255^{\mathrm{a} *}$ & 4.4 & 0.001 & 0.001 & 0.5 \\
\hline Proximal jejunum & $230^{\mathrm{a}}$ & $243^{\mathrm{a}}$ & 4.4 & & & \\
\hline Mid-jejunum & $196^{\mathrm{b}}$ & $215^{\mathrm{b}}$ & 4.4 & & & \\
\hline Distal jejunum & $235^{\mathrm{a}}$ & $247^{\mathrm{a}}$ & 4.4 & & & \\
\hline \multicolumn{7}{|c|}{ Villus height/crypt depth } \\
\hline Duodenum & $2.56^{\mathrm{b}}$ & 2.21 & 0.09 & 0.001 & 0.001 & 0.16 \\
\hline Proximal jejunum & $2.6^{\mathrm{b}}$ & 2.11 & 0.09 & & & \\
\hline Mid-jejunum & $3.35^{\mathrm{a}}$ & $2.59^{*}$ & 0.09 & & & \\
\hline Distal jejunum & $2.41^{\mathrm{b}}$ & 2.14 & 0.09 & & & \\
\hline
\end{tabular}

${ }^{\mathrm{a}, \mathrm{b}}$ Least squares means within a column with different lowercase letters are different $(P<0.05)$ among gut segments.

${ }^{1}$ Values are LSM, $\mathrm{n}=7$ per group.

*Least squares means between colostrum- and formula-fed calves (within a row) differ $(P<0.05)$. 
Table 2. Protein and nucleic acid content, mRNA expression, and activity of lactase, as well as mRNA expression and protein of glucose transporters sodium-dependent glucose co-transporter-1 (SGLT1) and facilitative glucose transporter (GLUT2) in different gut segments of neonatal calves fed with colostrum or formula for $4 \mathrm{~d}$ after birth ${ }^{1}$

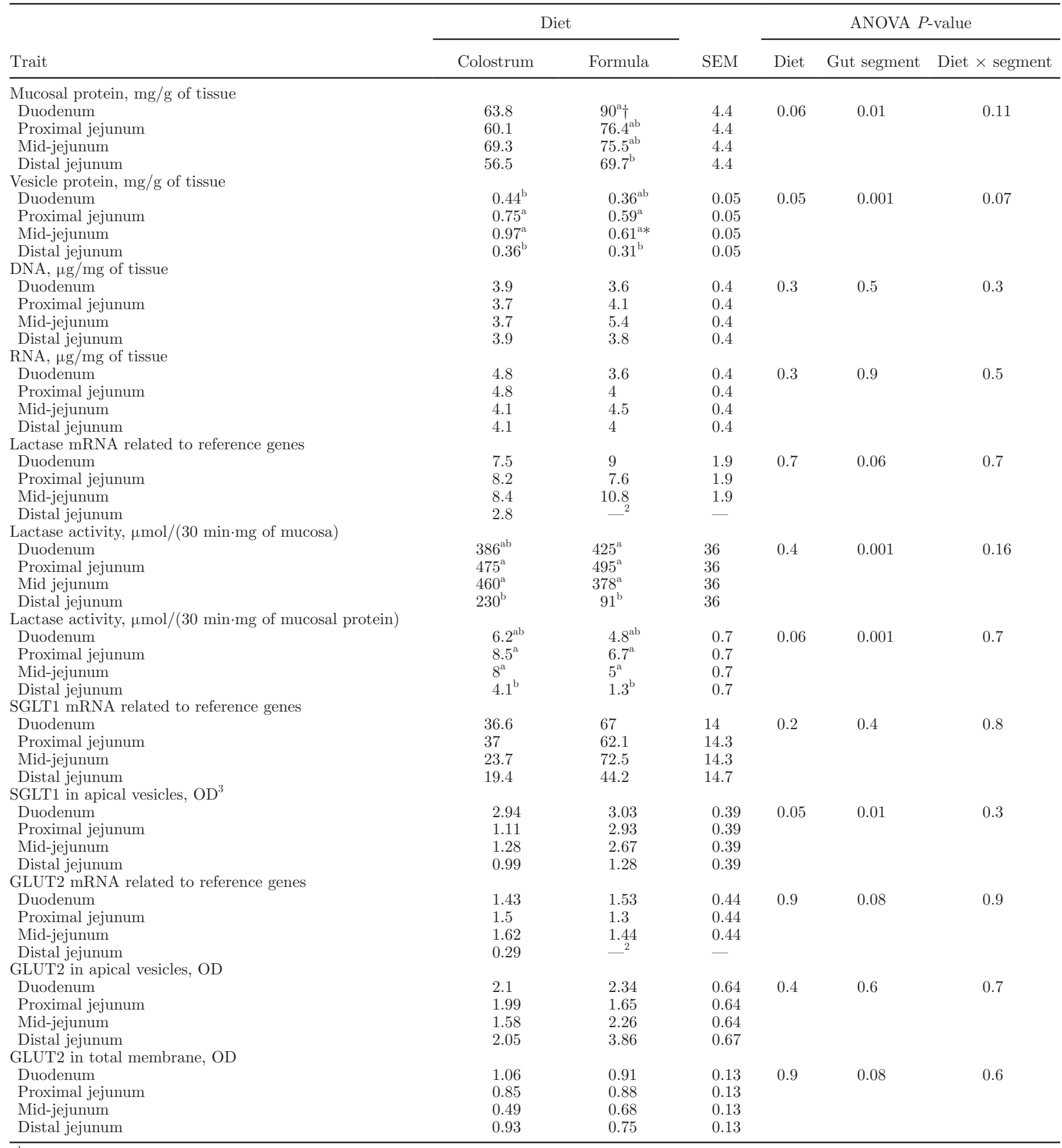

${ }^{\mathrm{a}, \mathrm{b}}$ Least squares means within a column with different lowercase letters are different $(P<0.05)$ among gut segments.

${ }^{1}$ Values are LSM, $\mathrm{n}=7$ per group.

${ }^{2}$ Not done.

${ }^{3} \mathrm{OD}=$ optical density.

${ }^{*} P<0.05 ; \dagger P<0.1$, indicating that LSM between colostrum- and formula-fed calves (within a row) differ. 
different parts of the small intestine are listed in Table 2 and did not show consistent effects related to diet and gut segment. Protein expression of glucose transporters SGLT1 and GLUT2 in different gut segments of the small intestine are shown in Table 2. Protein expression of SGLT1 indicated diet and gut segment effects with lower optical density $(P<0.05)$ of SGLT1 protein in $\mathrm{C}$ than in $\mathrm{F}$ and greater amounts $(P<0.01)$ of SGLT1 protein in duodenum than in distal jejunum. Protein expression of GLUT2 in total membranes, but not in apical vesicles, tended to be affected $(P<0.1)$ by gut segment.

In most sections examined immunohistochemically, light or moderate immunoreactivity for GLUT2 was observed in the apical and basolateral membrane of the epithelial cells. In general, GLUT2 immunoreactive ranking was higher in the proximal and medial jejunum than in the duodenum and distal jejunum. Also, the amounts of GLUT2 present in the apical or basolateral membrane compartment depended on gut segment (Figures 1 and 2). In the duodenum and proximal jejunum, immunoreactivity for GLUT2 was stronger in the apical than in the basolateral membrane. No differences between GLUT 2 expression in the apical and basolateral membrane could be detected in the medial and distal jejunum. The GLUT2 immunoreactivity was independent of feeding different diets.

\section{DISCUSSION}

\section{Colostrum Effects on Morphology}

The postnatal development of the small intestine is predominantly stimulated by colostrum intake in piglets and in calves (Widdowson et al., 1976; Odle et al., 1996; Blum, 2006). Colostrum intake in calves enhances villus size and reduces crypt depth, as suggested before (Bühler et al., 1998; Blättler et al., 2001), most likely due not only to provision of nutrients, minerals, and vitamins, but also due to effects of growth-promoting factors, as also seen in pigs (Kelly et al., 1993; Burrin et al., 1995; Xu et al., 2000). Because formula diets contain similar amounts of nutrients, especially lactose, but only trace amounts of hormones and other bioactive substances (Sauter et al., 2004; Steinhoff-Wagner et al., 2011), colostrum-specific bioactive factors may have been predominantly responsible for enhanced stimulation of villus growth and glucose absorption in C-fed calves also in the present study. In piglets, orally ingested IGF survive in the gut (Xu et al., 2000) and stimulate intestinal mucosal growth (Burrin et al., 1996). Oral administration of epidermal growth factor enhances gut growth in rat and mouse offspring (Arsenault and Menard, 1987; Berseth, 1987). In calves, co- lostral bioactive components stimulate mucosal growth and villus size after colostrum ingestion (Blum, 2006), but adding IGF-I to formula and feeding neonatal calves for $7 \mathrm{~d}$ results in inconsistent effects on villus growth (Baumrucker et al., 1994; Bühler et al., 1998; Roffler et al., 2003). However, feeding an extract derived from colostral whey proteins, including growth factors such as IGF-I, indicated slightly improved villus growth in the small intestine of neonatal calves (Roffler et al., 2003), indicating the concurrence of several growth promoting substances may be important for stimulation of intestinal growth.

Stimulation of villus growth after colostrum feeding might be the consequence of enhanced crypt fission, enhanced migration rate of crypt epithelial cells to villus tips, reduced apoptosis, or increased survival rate (as reviewed; Blum, 2006), whereas formula feeding induces apoptosis in preterm pigs (Oste et al., 2010). The greater villus height-to-crypt depth ratio in colostrumfed calves also indicated a more accelerated maturation of the gut mucosa in colostrum- than in formula-fed calves (Blum, 2006). Concerning glucose absorption, the slightly greater lactase activity in colostrum-fed calves may point at enhanced maturation processes in the mucosa of colostrum-fed calves.

Based on the requirements for successful mRNA extraction - chill tissue as fast as possible after removalwe were not able to measure the length of gut segments to calculate the total (potential) internal small intestinal absorptive surface. However, villus characteristics indicated that colostrum-fed calves had an overall larger surface area for nutrient absorption than formula-fed calves. Carbohydrate absorption, measured by xylose absorption test, was previously shown to be enhanced in colostrum-fed calves (Rauprich et al., 2000; Sauter et al., 2004). Our data support these findings and, more specifically, indicate greater absorption of labeled $\left[\mathrm{U}_{-}{ }^{13} \mathrm{C}\right]$-glucose fed to calves with colostrum than with formula feeding (Steinhoff-Wagner et al., 2011; Hammon et al., 2012).

\section{Colostrum Effects on Lactase Activity and Glucose Transport}

The administration of IGF-I, whose concentrations are very high in sow colostrum (Xu et al., 2002), enhances glucose absorption via suppression of the proteolytic degradation of lactase (Burrin et al., 2001) in piglets and by stimulation of small intestinal glucose transport (Alexander and Carey, 1999). Therefore, besides the elevated absorptive area, lactase activity or expression and production of glucose transporters in the small intestinal mucosa might be involved in promoting glucose absorption of colostrum-fed calves. Lactase 
A
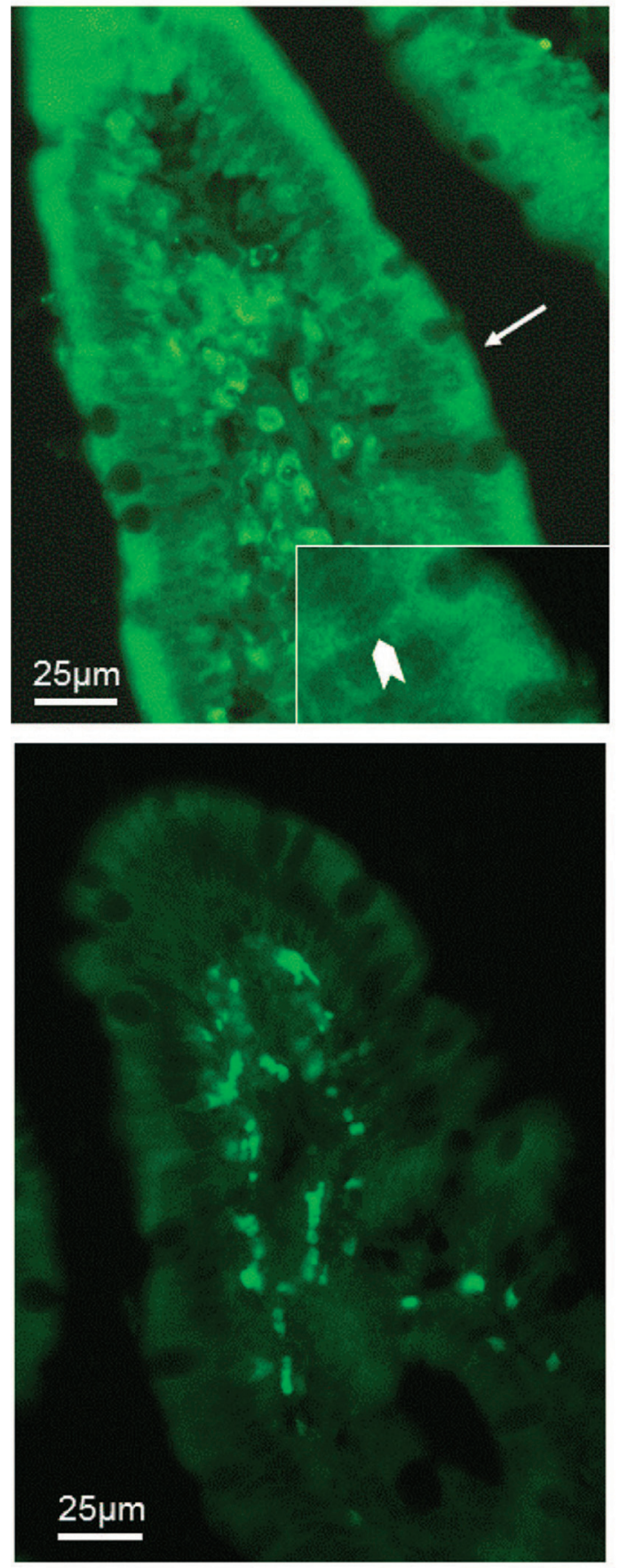

C
B
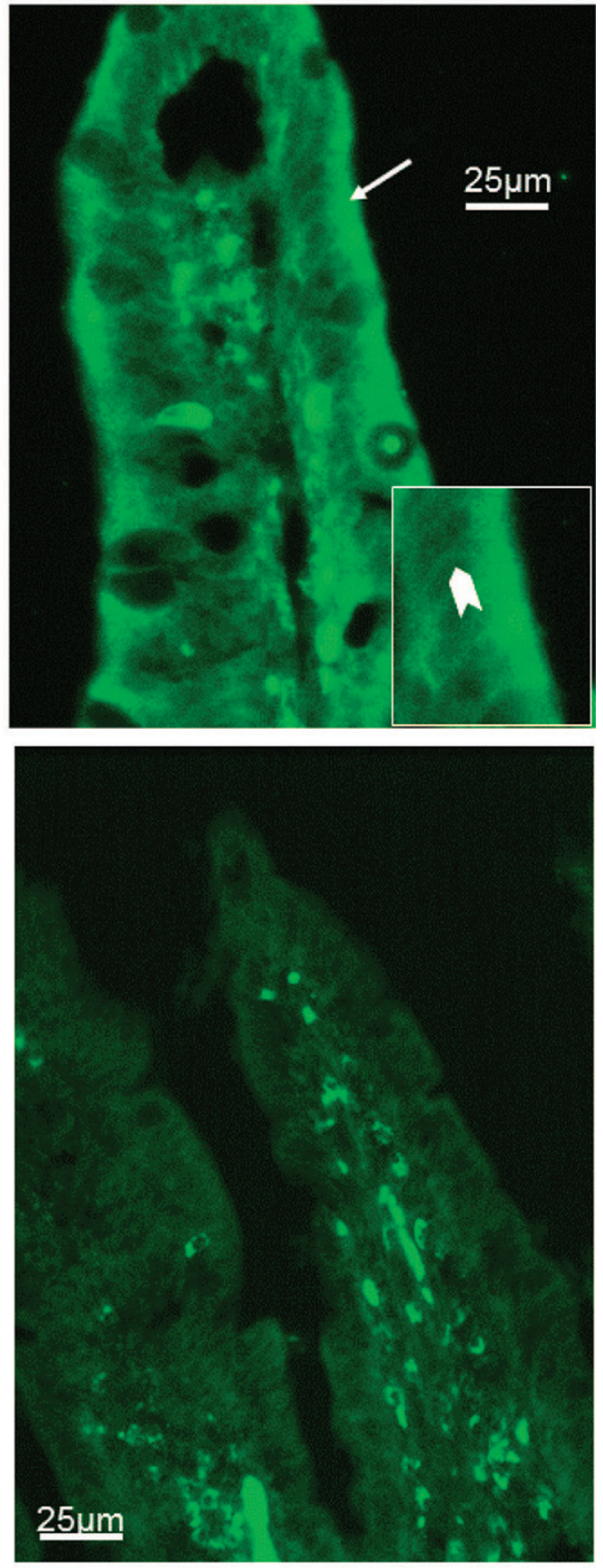

D

Figure 1. Immunofluorescence analysis of facilitative glucose transporter (GLUT2) protein in the small intestine of 4-d-old calves fed either colostrum (A) or formula (B). Immunofluorescence analysis was performed without anti-GLUT2 antibody in colostrum- (C) and formula-fed calves (D). Images shown are representative for the duodenal or jejunal segment. Small arrows highlight staining located apically, wide arrows basolaterally. 
mRNA expression and activity expressed per tissue was not affected by diet, and no effects of different feeding were seen in 5-d-old fasting calves (Sauter et al., 2004). However, lactase activity expressed per mucosal protein concentration tended to be greater in $\mathrm{C}$ than in $\mathrm{F}$. The greater lactase activity per mucosal protein was obviously a consequence of higher mucosal protein concentration in $\mathrm{F}$. The reasons for greater mucosal protein concentration in $\mathrm{F}$ are presently not known, but elevated protein concentrations in duodenal mucosa of F might possibly be the consequence of lactalbumin absorption and storage in enterocytes after first formula feeding, after which lactalbumin was probably not released to systemic circulation. However, we cannot exclude a greater protein synthesis or reduced protein degradation in mucosa cells of formula-fed calves. In contrast to mucosal protein concentration, vesicle protein concentration was greater in C than in F. Overall, our data support the concept that colostrum intake stimulates lactose digestion by coordinated stimulation of mucosal growth and cell function, an effect that is greater than in formula-fed calves, an interpretation supported by recent studies in neonatal pigs (Thymann et al., 2006). In contrast to lactase activity, lactase mRNA abundance did not respond to diet in our study.

The SGLT1 protein was more expressed in $\mathrm{F}$ than $\mathrm{C}$, which might be explained by dilution of SGLT1 protein by other proteins in C, because SGLT1 was measured in isolated BBMV proteins and vesicle protein content was higher in $\mathrm{C}$ than in F. Substitution of bioactive colostral proteins with sodium caseinate in formula achieved comparable amounts of protein as in C, but sodium casein might have stimulated SGLT1 in formula-fed calves (Freeman et al., 1993; Barfull et al., 2002). As indicated in our study, SGLT1 is barely regulated at the transcriptional level (Freeman et al., 1993), and the absolute number of SGLT1 transporters in the intestinal mucosa might be comparable between colostrum- and formula-fed calves because of the greater mucosal size and absorptive capacity in colostrumfed calves. In calves fasted for more than $16 \mathrm{~h}$, SGLT1 protein expression was not affected by diet (Hammon and Schönhusen, 2006).

In contrast to SGLT1, GLUT2 protein expression was not influenced by diet, supporting recent findings in colostrum- and formula-fed piglets that, too, did not show diet effects on GLUT2 protein expression in enterocytes (Thymann et al., 2006). A lack of dietary effects on GLUT2 gene and protein expression was also observed in dairy cows (Lohrenz et al., 2011). In addition, different diets did not change the distribution of GLUT2 protein between apical and basolateral localization in enterocytes.
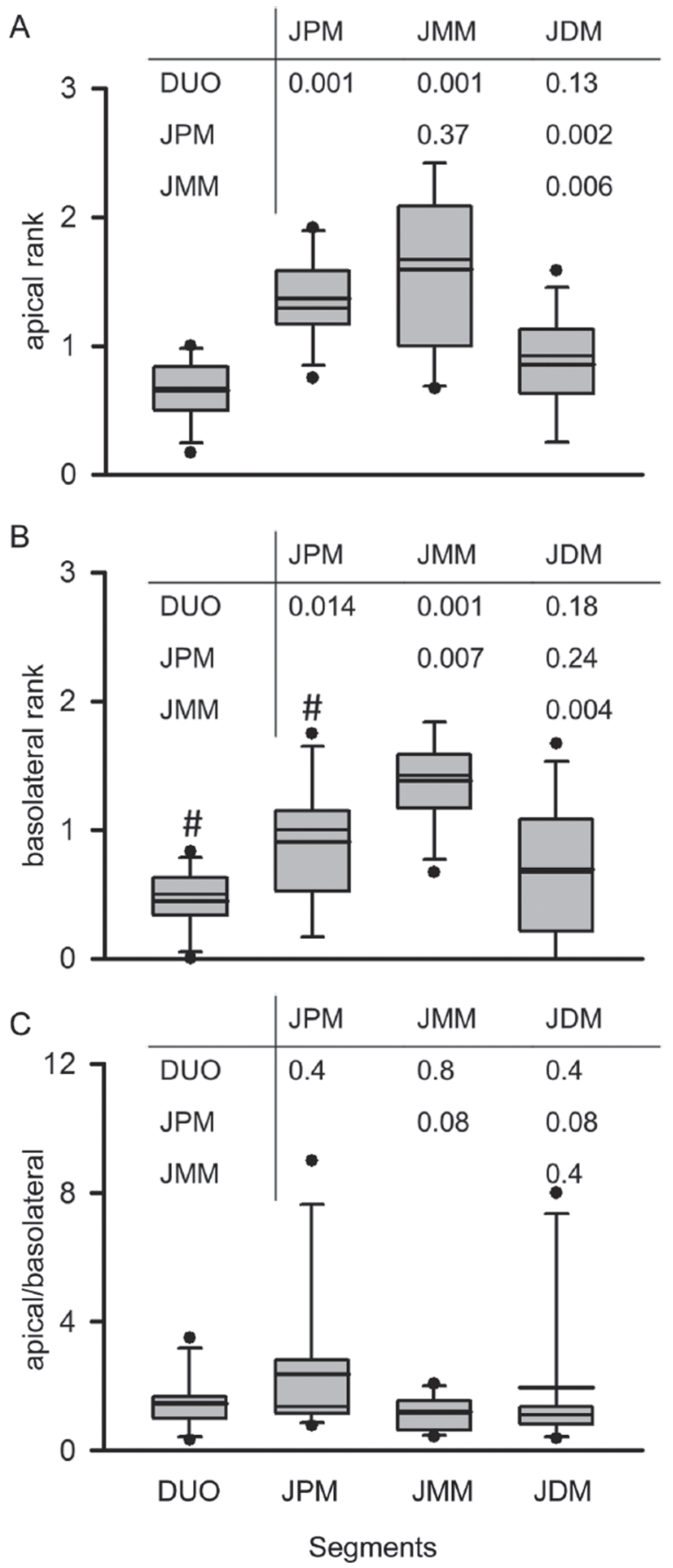

Figure 2. Box plots [box with 25th and 75th percentile, median (thin line) in the box, mean (thick line) in or outside of the box, error bars with 90 th and 10th percentiles, dots indicate outlying points] of ranked immunoreaction (scale $0-3$; intervals of 0.5 ; mean of 3 different samples per segment and individual calf) in different gut segments (regardless of diet): duodenum (DUO, $\mathrm{n}=12$ ), proximal $(J P M, \mathrm{n}=$ 12), mid- (JMM, $\mathrm{n}=11)$, and distal jejunum $(\mathrm{JDM}, \mathrm{n}=13)$ of apical (A) and basolateral (B) enterocyte membrane and ratio of apical to basolateral (C). Above plots, table of $P$-values of Wilcoxon 2-sample test between segments are shown. Differences (Wilcoxon 2-sample test, $P<0.05)$ between apical and basolateral membrane within a segment are marked with the pound symbol (\#) in graph B. 


\section{Lactase Activity and Glucose Transporters Along the Small Intestine of Newborn Calves}

Morphometric parameters and lactase activity are highly dependent on gut segments (Guilloteau et al., 2009). Gut segments within the jejunum differ markedly in their function, and separation is important to observe their detailed function and development. Main activities for glucose digestion and absorption are in the proximal and mid-jejunum (Bauer et al., 2001). Therefore, lowest lactase activity and less SGLT1 protein in our study were found in the distal part of the small jejunum. Distribution of glucose transporters and lactase activity along gut segments support the assumption that glucose transporters are regulated by available glucose concentration (Pfannkuche and Gäbel, 2009). An inverse relationship between SGLT1 and villus growth may indicate a compensatory effect in intestinal mucosa of calves when mucosal growth was impaired. A compensatory or a rapid catch-up effect is also suggested by proliferation of the intestinal mucosa based on identification of proliferating cells, which expressed protein Ki-67, a protein that is produced in proliferative cells (Blättler et al., 2001). Because proliferation peaks early after birth, the catch-up effect might be even greater with formula feeding for the first $3 \mathrm{~d}$ measured on $\mathrm{d} 4$ in comparison to the measurement on d 8 of life (Blättler et al., 2001).

Interestingly, GLUT2 protein was found in the BBMV, which confirms previous findings of GLUT2 protein localization in BBMV of pigs, sheep, and cows (Kellett et al., 2008; Lohrenz et al., 2011). Appearance of GLUT2 in BBMV was supported by localization on the apical membrane of enterocytes via immunohistochemistry. This indicates a role for GLUT2 in apical glucose absorption, as recently asserted in rats (Kellett and Helliwell, 2000; Au et al., 2002) and cows (Lohrenz et al., 2011), and might explain why phlorizin failed to block glucose transport in suckling and mature rats as was the case in weaned rats (Drozdowski et al., 2010). Based on immunohistochemical findings GLUT2 protein was present in highest amounts at the apical and basolateral site of proximal and mid-jejunum, which fits with the localization of greatest lactose digestion (Guilloteau et al., 2009).

In conclusion, better conditions for glucose absorption in colostrum-fed calves are mainly caused by a greater absorptive area as a consequence of greater intestinal growth and, thus, absorptive surface, whereas lactase activity is slightly stimulated and intestinal glucose transporters are not increased when colostrum feeding is compared with formula feeding. Therefore, enhanced postnatal intestinal mucosa growth can improve glucose absorption in colostrum-fed calves without stimulating abundance of intestinal glucose transporters.

\section{ACKNOWLEDGMENTS}

We thank A. Zeyner from University of Rostock (Dummerstorf, Germany) and her staff for providing the experimental facility; B. Waischnow, C. Reiko, M. Althaus, B. Kuhla, S. Kuhla, H. Schott, G. Nehring, and J. Petschow [all from Leibniz Institute for Farm Animal Biology (FBN), Dummerstorf, Germany] for excellent assistance during sampling; and I. Workel (FBN) for analytical assistance. We thank Bergophor Futtermittelfabrik GmbH (Kulmbach, Germany) for donating the formulas and EW Nutrition GmbH (Visbek, Germany) for donating the feed additive Globigen 88. The financial support by Deutsche Forschungsgemeinschaft (DFG, Bonn, Germany) is also gratefully acknowledged (HA 4372/5-1).

\section{REFERENCES}

Alexander, A. N., and H. V. Carey. 1999. Oral IGF-I enhances nutrient and electrolyte absorption in neonatal piglet intestine. Am. J. Physiol. 277:G619-G625.

Arsenault, P., and D. Menard. 1987. Stimulatory effects of epidermal growth factor on deoxyribonucleic acid synthesis in the gastrointestinal tract of the suckling mouse. Comp. Biochem. Physiol. B $86: 123-127$

Au, A., A. Gupta, P. Schembri, and C. I. Cheeseman. 2002. Rapid insertion of GLUT2 into the rat jejunal brush-border membrane promoted by glucagon-like peptide 2. Biochem. J. 367:247-254.

Barfull, A., C. Garriga, A. Tauler, and J. M. Planas. 2002. Regulation of SGLT1 expression in response to $\mathrm{Na}^{+}$intake. Am. J. Physiol. Regul. Integr. Comp. Physiol. 282:R738-R743.

Bauer, M. L., D. L. Harmon, D. W. Bohnert, A. F. Branco, and G. B. Huntington. 2001. Influence of alpha-linked glucose on sodiumglucose cotransport activity along the small intestine in cattle. J. Anim. Sci. 79:1917-1924.

Baumrucker, C. R., and J. W. Blum. 1994. Effects of dietary recombinant human insulin-like growth factor-I on concentrations of hormones and growth factors in the blood of newborn calves. J. Endocrinol. 140:15-21.

Baumrucker, C. R., D. L. Hadsell, and J. W. Blum. 1994. Effects of dietary insulin-like growth factor I on growth and insulin-like growth-factor receptors in neonatal calf intestine. J. Anim. Sci. 72:428-433.

Berseth, C. L. 1987. Enhancement of intestinal growth in neonatal rats by epidermal growth factor in milk. Am. J. Physiol. 253:G662G665.

Bird, A. R., W. J. Croom, Y. K. Fan, B. L. Black, B. W. McBride, and I. L. Taylor. 1996. Peptide regulation of intestinal glucose absorption. J. Anim. Sci. 74:2523-2540.

Blättler, U., H. M. Hammon, C. Morel, C. Philipona, A. Rauprich, V. Rome, I. Le Huerou-Luron, P. Guilloteau, and J. W. Blum. 2001. Feeding colostrum, its composition and feeding duration variably modify proliferation and morphology of the intestine and digestive enzyme activities of neonatal calves. J. Nutr. 131:1256-1263.

Blum, J. W. 2006. Nutritional physiology of neonatal calves. J. Anim. Physiol. Anim. Nutr. (Berl.) 90:1-11.

Blum, J. W., and H. Hammon. 2000. Colostrum effects on the gastrointestinal tract, and on nutritional, endocrine and metabolic parameters in neonatal calves. Livest. Prod. Sci. 66:151-159. 
Bradford, M. M. 1976. A rapid and sensitive method for the quantitation of microgram quantities of protein utilizing the principle of protein-dye binding. Anal. Biochem. 72:248-254.

Bühler, C., H. Hammon, G. L. Rossi, and J. W. Blum. 1998. Small intestinal morphology in eight-day-old calves fed colostrum for different durations or only milk replacer and treated with long-R3-insulin-like growth factor I and growth hormone. J. Anim. Sci. 76:758-765.

Burrin, D. G., T. A. Davis, S. Ebner, P. A. Schoknecht, M. L. Fiorotto, P. J. Reeds, and S. McAvoy. 1995. Nutrient-independent and nutrient-dependent factors stimulate protein synthesis in colostrumfed newborn pigs. Pediatr. Res. 37:593-599.

Burrin, D. G., B. Stoll, M. Z. Fan, M. A. Dudley, S. M. Donovan, and P. J. Reeds. 2001. Oral IGF-I alters the posttranslational processing but not the activity of lactase-phlorizin hydrolase in formulafed neonatal pigs. J. Nutr. 131:2235-2241.

Burrin, D. G., T. J. Wester, T. A. Davis, S. Amick, and J. P. Heath 1996. Orally administered IGF-I increases intestinal mucosal growth in formula-fed neonatal pigs. Am. J. Physiol. 270:R1085R1091.

Drozdowski, L. A., T. Clandinin, and A. B. Thomson. 2010. Ontogeny, growth and development of the small intestine: Understanding pediatric gastroenterology. World J. Gastroenterol. 16:787-799.

Freeman, T. C., I. S. Wood, D. J. S. Sirinathsinghji, R. B. Beechey, J Dyer, and S. P. Shirazi-Beechey. 1993. The expression of the $\mathrm{Na}^{+} /$ glucose cotransporter $(S G L T 1)$ gene in lamb small intestine during postnatal development. Biochim. Biophys. Acta 1146:203-212.

Fujita, M., H. Matsui, K. Nagano, and M. Nakao. 1971. Asymmetric distribution of ouabain-sensitive ATPase activity in rat intestinal mucosa. Biochim. Biophys. Acta 233:404-408.

Gauthier, S. F., Y. Pouliot, and J. L. Maubois. 2006. Growth factors from bovine milk and colostrum: Composition, extraction and biological activities. Lait 86:99-125.

Girard, J. 1990. Metabolic adaptations to change of nutrition at birth. Biol. Neonate 58(Suppl. 1):3-15.

Grütter, R., and J. W. Blum. 1991. Insulin and glucose in neonatal calves after peroral insulin and intravenous glucose-administration. Reprod. Nutr. Dev. 31:389-397.

Guilloteau, P., R. Zabielski, and J. W. Blum. 2009. Gastrointestinal tract and digestion in the young ruminant: Ontogenesis, adaptations, consequences and manipulations. J. Physiol. Pharmacol. $60: 37-46$

Hammon, H., and J. W. Blum. 1997a. Prolonged colostrum feeding enhances xylose absorption in neonatal calves. J. Anim. Sci. 75:2915-2919.

Hammon, H., and J. W. Blum. 1997b. The somatotropic axis in neonatal calves can be modulated by nutrition, growth hormone, and long-R-3-IGF-I. Am. J. Physiol. 273:130-138.

Hammon, H. M., and U. Schönhusen. 2006. Effects of colostrum (C) feeding and dexamethasone (Dexa) treatment on sodium-dependent glucose co-transporter-1 (SGLT1) in the small intestine of neonatal calves. J. Anim. Sci. 84(Suppl. 1):31.

Hammon, H. M., J. Steinhoff-Wagner, J. Flor, U. Schönhusen, and C. C. Metges. 2013. Role of colostrum and colostrum components on glucose metabolism in neonatal calves. J. Anim. Sci. 91:685-695.

Hammon, H. M., J. Steinhoff-Wagner, U. Schönhusen, C. C. Metges, and J. W. Blum. 2012. Energy metabolism in the newborn farm animal with emphasis on the calf: Endocrine changes and responses to milk-born and systemic hormones. Domest. Anim. Endocrinol. 43:171-185.

Hammon, H. M., G. Stürmer, F. Schneider, A. Tuchscherer, H. Blum, T. Engelhard, A. Genzel, R. Staufenbiel, and W. Kanitz. 2009. Performance and metabolic and endocrine changes with emphasis on glucose metabolism in high-yielding dairy cows with high and low fat content in liver after calving. J. Dairy Sci. 92:1554-1566.

Kellett, G. L., E. Brot-Laroche, O. J. Mace, and A. Leturque. 2008. Sugar absorption in the intestine: The role of GLUT2. Annu. Rev. Nutr. 28:35-54

Kellett, G. L., and P. A. Helliwell. 2000. The diffusive component of intestinal glucose absorption is mediated by the glucose-induced recruitment of GLUT2 to the brush-border membrane. Biochem. J. 350:155-162.

Kelly, D., T. P. King, M. McFadyen, and A. G. Coutts. 1993. Effect of preclosure colostrum intake on the development of the intestinal epithelium of artificially reared piglets. Biol. Neonate 64:235-244.

Kühne, S., H. M. Hammon, R. M. Bruckmaier, C. Morel, Y. Zbinden, and J. W. Blum. 2000. Growth performance, metabolic and endocrine traits, and absorptive capacity in neonatal calves fed either colostrum or milk replacer at two levels. J. Anim. Sci. 78:609-620.

Lee, C. Y., H. H. Head, C. R. Feinstein, J. Hayen, and F. A. Simmen. 1995. Endocrine changes and circulating insulin-like growth factors in newborn calves fed colostrum, milk or milk replacer. Asianaustralas. J. Anim. Sci. 8:51-58.

Lohrenz, A. K., K. Duske, U. Schönhusen, B. Losand, H. M. Seyfert, C. C. Metges, and H. M. Hammon. 2011. Glucose transporter and enzymes related to glucose synthesis in small intestinal mucosa of dairy cows fed either a starch-based or a diet containing rumenprotected fat. J. Dairy Sci. 94:4546-4555.

Michanek, P., M. Ventorp, and B. Westrom. 1990. Milk intake before first colostrum in newborn dairy calves - Effect on intestinal transmission of macromolecules. J. Dairy Sci. 73:480-483.

Mir, P. S., D. R. C. Bailey, Z. Mir, S. D. Morgan Jones, H. Douwes, T. A. McAllister, R. J. Weselake, and F. J. Lozeman. 1997. Activity of intestinal mucosal membrane carbohydrases in cattle of different breeds. Can. J. Anim. Sci. 77:441-446.

Odle, J., R. T. Zijlstra, and S. M. Donovan. 1996. Intestinal effects of milkborne growth factors in neonates of agricultural importance. J. Anim. Sci. 74:2509-2522.

Ontsouka, E. C., B. Korczak, H. M. Hammon, and J. W. Blum. 2004. Real-time PCR quantification of bovine lactase mRNA: Localization in the gastrointestinal tract of milk-fed calves. J. Dairy Sci. $87: 4230-4237$

Oste, M., E. van Haver, T. Thymann, P. Sangild, A. Weyns, and C. J. van Ginneken. 2010. Formula induces intestinal apoptosis in preterm pigs within a few hours of feeding. JPEN J. Parenter. Enteral. Nutr. 34:271-279.

Pfaffl, M. W. 2001. A new mathematical model for relative quantification in real-time RT-PCR. Nucleic Acids Res. 29:e45.

Pfannkuche, H., and G. Gäbel. 2009. Glucose, epithelium, and enteric nervous system: Dialogue in the dark. J. Anim. Physiol. Anim. Nutr. (Berl.) 93:277-286.

Pfannkuche, H., F. Taifour, J. Steinhoff-Wagner, H. M. Hammon, and G. Gäbel. 2014. Postnatal changes of MCT1 expression in the forestomach of calves. J. Anim. Physiol. Anim. Nutr. (Berl.) 98:140-148.

Rauprich, A. B. E., H. M. Hammon, and J. W. Blum. 2000. Effects of feeding colostrum and a formula with nutrient contents as colostrum on metabolic and endocrine traits in neonatal calves. Biol. Neonate 78:53-64.

Roffler, B., A. Fah, S. N. Sauter, H. M. Hammon, P. Gallmann, G Brem, and J. W. Blum. 2003. Intestinal morphology, epithelial cell proliferation, and absorptive capacity in neonatal calves fed milkborn insulin-like growth factor-I or a colostrum extract. J. Dairy Sci. 86:1797-1806.

Sauter, S. N., B. Roffler, C. Philipona, C. Morel, V. Rome, P. Guilloteau, J. W. Blum, and H. M. Hammon. 2004. Intestinal development in neonatal calves: Effects of glucocorticoids and dependence on colostrum feeding. Biol. Neonate 85:94-104.

Scharrer, E., and B. Grenacher. 2000. $\mathrm{Na}^{+}$-Dependent transport of D-xylose by bovine intestinal brush border membrane vesicles (BBMV) is inhibited by various pentoses and hexoses. J. Vet. Med. A. Physiol. Clin. Med. 47:617-626.

Schröder, B., and G. Breves. 1996. Mechanisms of phosphate uptake into brush border membrane vesicles from goat jejunum. J. Comp. Physiol. B 166:230-240.

Shirazi-Beechey, S. P., I. S. Wood, J. Dyer, D. Scott, and T. P. King 1995. Intestinal sugar transport in ruminants. Pages 117-33 in Ruminant Physiology. W. von Engelhardt, S. Leonhard-Marek, G. Breves, and D. Gieseke, ed. Ferdinand Enke Verlag, Stuttgart, Germany. 
Simmen, F. A., K. R. Cera, and D. C. Mahan. 1990. Stimulation by colostrum or mature milk of gastrointestinal tissue-development in newborn pigs. J. Anim. Sci. 68:3596-3603.

Steinhoff-Wagner, J., S. Görs, P. Junghans, R. M. Bruckmaier, E. Kanitz, C. C. Metges, and H. M. Hammon. 2011. Intestinal glucose absorption but not endogenous glucose production differs between colostrum- and formula-fed neonatal calves. J. Nutr. 141:48-55.

Thymann, T., D. G. Burrin, K. A. Tappenden, C. R. Bjornvad, S. K. Jensen, and P. T. Sangild. 2006. Formula-feeding reduces lactose digestive capacity in neonatal pigs. Br. J. Nutr. 95:1075-1081.

Tivey, D. R., J. Le Dividich, P. Herpin, D. Brown, and M. J. Dauncey. 1994. Differential effects of lipid and carbohydrate on enterocyte lactase activity in newborn piglets . Exp. Physiol. 79:189-201.

Vacher, P. Y., G. Bestetti, and J. W. Blum. 1995. Insulin-like growth factor I absorption in the jejunum of neonatal calves. Biol. Neonate 68:354-367.
Widdowson, E. M., V. E. Colombo, and C. A. Artavanis. 1976. Changes in the organs of pigs in response to feeding for the first $24 \mathrm{~h}$ after birth. II. The digestive tract. Biol. Neonate 28:272-281.

Xu, R. J., P. T. Sangild, Y. Q. Zhang, and S. H. Zhang. 2002. Bioactive compounds in porcine colostrum and milk and their effects on intestinal development in neonatal pigs. Pages 169-92 in Biology of the Intestine in Growing Animals: Developments in Animal and Veterinary Sciences. R. Zabielski, S. Pierzynowski, and B. Westrom, ed. Elsevier, Amsterdam, the Netherlands.

Xu, R. J., F. Wang, and S. H. Zhang. 2000. Postnatal adaptation of the gastrointestinal tract in neonatal pigs: A possible role of milkborne growth factors. Livest. Prod. Sci. 66:95-107.

Zitnan, R., J. Voigt, S. Kuhla, J. Wegner, A. Chudy, U. Schönhusen, M. Brna, M. Zupcanova, and H. Hagemeister. 2008. Morphology of small intestinal mucosa and intestinal weight change with metabolic type of cattle. Vet. Med. (Praha) 53:525-532. 